\title{
Policy Frameworks and Institutions for Decarbonisation: The Energy Sector as 'Litmus Test'
}

\author{
LYNETTE MOLYNEAUX AND KEITH SUE
}

\section{Executive Summary}

As a global community, we have known about the threats associated with the burning of fossil fuels for several decades, and yet greenhouse gas emissions have continued to increase. This is as a result of the perceived economic imperative of cheap energy from fossil fuels, complex technological and institutional structures that govern investment and supply of energy, the power of fossil fuel vested interests to direct the political discourse towards inaction, and a global decarbonisation framework which is effectively uncoupled from global trade rules. Building a successful policy framework requires a nod to each of these complexities. In this chapter we look to the energy sector to explain how these complexities have affected the success of decarbonisation plans and what can be done to mitigate against their hindrance of success.

We discuss how context matters and that there is no single framework that works. Each country or region needs to account for the specifics of their energy system, institutional structures, public expectations, level of development and political context in policy formulation. The chapter therefore gives consideration to the tools that can be included within the policy framework that will suit the expectations of a diversity of public views on the need to decarbonise. We conclude with a discussion on the challenges that need to be confronted to achieve intended outcomes.

\subsection{Why Climate and Energy Policy Is on the Critical Path to Decarbonisation}

The combustion of fossil fuels produces $73 \%$ of annual global greenhouse gas (GHG) emissions. The largest sectoral consumer of fossil fuel is electricity and heat generation, which contributes $30 \%$ to GHG emissions, followed by industrial, construction and mining processes, which contribute $32 \%$ to annual totals, and transport, which contributes $16 \%$ (CAIT 2019). Agriculture contributes 12\%, land use, land-use change and forestry contribute $7 \%$ and waste, $3 \%$. Climate policy therefore has to accommodate varying scope and scale to reach all sectoral processes which result in GHG emissions. It is an economy-wide challenge, with almost no sector or industry immune from the need to reduce emissions.

Inevitably, then, designing and implementing comprehensive, effective climate policy involves hard political choices: prioritising between options which could result in 
suboptimal outcomes, and attempting to resolve inequitable distributional consequences. The stakes are high and mobilisation of power by fossil fuel regimes is large, such that the temptation for politicians to defer the big decisions is strong (Meadowcroft 2011). Politicians may reference uneven global decarbonisation action, which results in decreased international competitiveness and general concerns about increasing costs for voters as justification for limiting climate and energy policy. The inertia from national governments despite commitments made in the Paris Agreement $^{1}$ is testament to the strength of these arguments.

This chapter discusses the complexity and challenges inherent in developing climate policy through the lens of the energy sector. Emissions from the generation of electricity form the major contribution to most countries' carbon budgets because coal, a carbonintensive fuel, geographically dispersed around the world, has been the preferred, and, until recently, most affordable, fuel for electricity generation. Electricity generation is the largest contributor to GHG emissions, and the Climate Change Authority in the UK concluded that 'any path to an $80 \%$ reduction by 2050 requires that electricity generation is almost entirely decarbonised by 2030' (UK CCC 2008: 173). Similarly, the European Commission's Roadmap for Moving to a Competitive Low Carbon Economy in 2050 finds that '[e]lectricity will play a central role in the low carbon economy' (European Commission 2011: 6). Decarbonisation plans therefore commonly focus on electricity, with additional policy measures to address emissions in the other sectors, including regulation to address energy efficiency, taxes and land clearing. As is clear from our analysis, many of the bottlenecks experienced in the energy sector are not unique to that sector, and indeed there are many similarities with decarbonisation efforts in the transport, agriculture and built environment sectors - such is the case with profound structural change.

The chapter begins by focusing on the complexities associated with electricity supply and other industry and transport sectors, then moves on to the tools required for a coherent policy framework and finishes with a detailed discussion on the challenges to confront in decarbonising the energy sector.

\subsubsection{Electricity Generation}

The sector has complex technical and institutional characteristics, which require powerful policy frameworks to regulate and facilitate change. A discussion of these complexities follows.

\subsubsection{Technological Complexity}

Large power plants are constructed to gain economies of scale and reduce the unit cost of electricity. Capital cost for a 1000-MW power plant ranges from USD 0.7-1.3 billion for a combined-cycle gas turbine, USD 3.0-6.2 billion for a coal-fired power station, to USD 6.9-12.2 billion for a nuclear power plant (Lazard 2019). Greater utilisation of power

\footnotetext{
${ }^{1}$ Paris Agreement Under the United Nations Framework Convention on Climate Change, opened for signature 16 February
} 2016. Available at: https://unfccc.int/process-and-meetings/the-paris-agreement/the-paris-agreement. 
plants can be gained by transferring electricity between consumption regions as demand varies using electricity networks. The scale of investment requires detailed planning and stakeholder buy-in, with large risks for investors and financiers who in turn seek secure returns from long periods of operation. The power grid connects every generator to every consumer, supplying power to meet demand, all and every day, making operation and management extremely complex.

Technological innovation in the electricity sector is increasing this complexity. Energy dispatched from variable sources or discharged from stored energy needs to be integrated with existing, less flexible technologies to ensure grid stability. Demand-side innovation has been slow to emerge because of the challenges associated with motivating individual actors to respond dynamically.

\subsubsection{Institutional Complexity}

\section{Governance and Regulation}

Where electricity systems have not been liberalised, they are generally operated as vertically integrated utilities, with governance structures dictated by state actors. Utilities provide advice to politicians on operational and strategic requirements, and politicians direct utilities according to political commitments.

From the mid-1990s, liberalisation of the electricity sector has led to the dismantling of vertically integrated utilities, which involved: introducing competition among generators to supply electricity to a centralised electricity market, and among retailers to supply electricity to consumers; and the regulation of network organisations with respect to returns and investment. While many countries and states have pursued liberalisation, implementations stalled after flaws were exposed in California's electricity market in 2000. Changes to market designs resolved the flaws, but the consequence was that national/regional electricity sectors are often characterised by a mix of public and private, vertically integrated utilities and independent power producers and retailers, functioning alongside each other. Governance arrangements have sought to encompass a broad range of responsibilities, including the establishment of legislative frameworks, the definition and implementation of operational standards and rules, and the regulation of industry participants. Electricity sectors are often complicated by a 'mixed-model energy governance structure' where the regions/states are responsible for the provision of electricity but the sector is subject to national/federal electricity governance, oversight and planning (Osofsky and Wiseman 2014; Warren et al. 2016).

\section{Institutions and Path Dependence}

In large technical systems such as electricity networks, technological infrastructures and the institutional frameworks which support them are tightly bound and co-evolutionary (Künneke 2008). Dominant design theorists argue that such systems develop along a predictable pathway (Nelson 1995) and culminate in the emergence of a dominant technology class (Anderson and Tushman 1990). Upon establishment as the dominant design, the technology class is reinforced by institutional biases to gain precedence over other, 
potentially superior, designs (Arthur 1989). An extension of this theory of path dependency by Gregory Unruh (2000) moves beyond the genesis of an industry and the competition to establish any given technology as the dominant design; instead addressing the technoinstitutional relationship in a mature system. Unruh specifically focuses on the electricity industry in the context of emission-intensive generation and argues that the development of technological trajectories in conjunction with the institutional environment establishes a positive feedback between institutions and a particular technology class, leading to a 'lock out' of emerging technologies - which he describes as a techno-institutional complex. It has been argued that the propensity for new technologies to be 'locked out' of a system due to ideological inertia is further reinforced by the disparity between the rapid development of technological pathways and the comparatively slow pace of regulatory and institutional change (Williamson 1998; Künneke 2008). It follows that these two aspects form an internal ideological force acting to maintain the status quo in technical systems such as electricity networks.

Due to the inherent bias towards this dominant technology class, it could be argued that technologies external to the current framework, such as renewable forms of electricity generation, energy storage, energy efficiency technologies and demand management, may struggle to integrate. Industries operating in flexible and adaptable environments may embrace such technologies - termed disruptive technologies - and radically change the industrial paradigm through a discontinuous transition to a new dominant design (Christensen 1997). Rapidly integrating large-scale technological disruption into the supply of electricity, in a potentially rigid and unresponsive institutional environment, may lead to detrimental operation at both a technical and market level.

This techno-institutional complexity means that the challenges confronting policymakers in their endeavour to develop more sustainable electricity systems are manifold. These challenges transcend simple policy formulation, and require a detailed appreciation for competing sociopolitical objectives and institutional inertia (Figure 1.1). Those embarking on electricity market reform for decarbonisation must recognise that institutional innovation is required to support the entry of new technologies and business models, but the risks they may pose to the existing system must be managed. Ideally, the design of the policy framework should maximise technological flexibility, while managing policy objectives.

\subsubsection{Competing Objectives of Electricity Policy}

In considering specific policy frameworks to drive the decarbonisation of the electricity sector, we must first recognise that there are a range of other policy objectives which must be managed and prioritised in a coherent manner. These objectives underpin existing sectoral institutional structures, and the broader energy policy frameworks. While this may appear to be quite obvious, the tensions between competing objectives can be easily overlooked in the heat of policy formulation; that is, until one is confronted with a suboptimal mix of unanticipated outcomes. Any discussion surrounding effective sectoral decarbonisation policies must, then, acknowledge the breadth of policy objectives relevant 


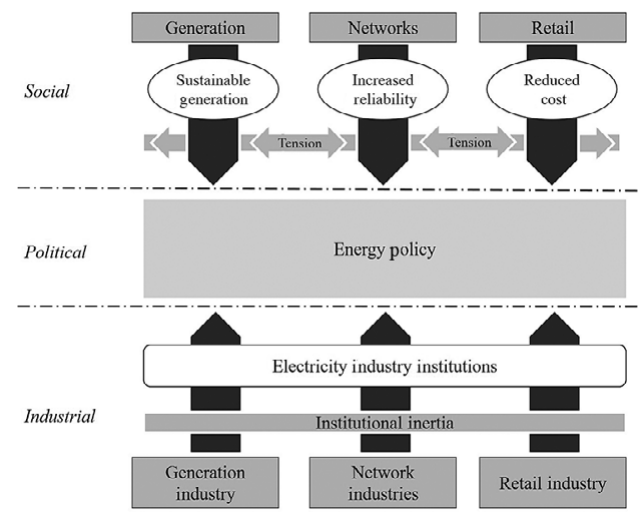

Figure 1.1 Social interactions in electricity markets.

Source: Courtesy of the authors. Note, the sociopolitical objectives (white circles) influence policy at both the federal and jurisdictional level. These objectives can be conflicting, as shown here. An additional tension exists between the inherent institutional inertia and desired social change (Sue et al. 2014).

to electricity provision and market design, and highlight the limitations that conflicting objects can impose.

\section{Context Matters}

The stark contrast between electricity provision in the developed and developing world highlights the contextual nature of objectives. Developed nations exhibiting welldeveloped electricity industries have traditionally been focused on reliability of service and energy security. In contrast, developing nations are clearly more directed towards availability and affordability of electricity supply. The push towards more sustainable electricity provision in the previous two decades interacts with these two dynamics in contrasting ways. For developed countries, the focus has been largely placed on the integration of renewable energy (RE) systems into existing systems. In contrast, for developing countries, availability of electricity supply is affected by the remoteness of communities and, because household demand exists for only a few hours a day, and efficient coal, nuclear and some gas power stations have minimum stable operating levels for all 24 hours per day, industry demand is required in conjunction with household demand, to make electricity technically and economically feasible for households and small commercial consumers.

In many cases, decentralised RE systems can be the primary vehicle for access to electricity in remote locations. A recent International Energy Agency (IEA) report finds that decentralised, renewable energy is the least-cost way to provide power to more than half of the population gaining access by 2030 (IEA 2019a).

\section{Availability and Access}

Although considerable policy focus to date has been placed on lifting regions out of energy poverty, access to electricity in many developing regions remains poor (Table 1.1). This is 
Table 1.1. Access to electricity in developing regions

\begin{tabular}{|c|c|c|c|c|}
\hline Region & $\begin{array}{l}\text { Population without } \\
\text { electricity (millions) }\end{array}$ & $\begin{array}{l}\text { Electrification } \\
\text { rate }(\%)\end{array}$ & $\begin{array}{l}\text { Urban } \\
\text { electrification } \\
\text { rate }(\%)\end{array}$ & $\begin{array}{l}\text { Rural electrification } \\
\text { rate }(\%)\end{array}$ \\
\hline $\begin{array}{l}\text { Developing } \\
\text { countries }\end{array}$ & 860 & 86 & 95 & 77 \\
\hline Africa & 595 & 54 & 79 & 35 \\
\hline North Africa & 1 & $>99$ & $>99$ & $>99$ \\
\hline $\begin{array}{l}\text { Sub-Saharan } \\
\text { Africa }\end{array}$ & 594 & 45 & 74 & 26 \\
\hline $\begin{array}{l}\text { Developing } \\
\text { Asia }\end{array}$ & 230 & 94 & 98 & 91 \\
\hline China & 3 & $>99$ & $>99$ & $>99$ \\
\hline India & 74 & 95 & $>99$ & 92 \\
\hline Indonesia & 5 & 98 & $>99$ & 96 \\
\hline $\begin{array}{l}\text { Other South } \\
\text { East Asia }\end{array}$ & 46 & 90 & 97 & 83 \\
\hline $\begin{array}{l}\text { Other } \\
\text { developing Asia }\end{array}$ & 103 & 79 & 89 & 73 \\
\hline $\begin{array}{l}\text { Central/South } \\
\text { America }\end{array}$ & 16 & 97 & 99 & 88 \\
\hline Middle East & 19 & 93 & 98 & 78 \\
\hline World & 862 & 89 & 96 & 79 \\
\hline
\end{tabular}

Note: Access shown as absolute figures and percentage levels, as assessed by the IEA in 2018.

Source: Adapted from IEA (2019a).

most pronounced in sub-Saharan Africa, where $74 \%$ of the rural population has no access to electricity. Achieving $100 \%$ electrification requires investment of USD 40 billion a year (IEA 2019a).

The deployment of low-carbon technologies has been seen as a key pillar to achieve these goals. In attempting to balance supply availability and environmental impact through RE systems, we are confronted by issues of affordability and access. Thus, requirements must be tempered by the financial resources of consumers to pay for availability and service levels.

\section{Security of Supply}

Security objectives focus on constraints to meet the required demand. Typically, these are framed across two dimensions: resource availability and the capacity of the electricity system to couple supply and demand. Resource availability has traditionally been the cornerstone issue for national supply security concerns. For example, until 2010, the current mix of fuel sources for the electricity industry in the USA grew largely out of the oil crises throughout the 1970s, where investment in coal power generation was required in preference to other fuel sources (US DoE 1978). A more contemporary example is that of 
Germany which has, in recent years, attempted to become more energy self-sufficient to decrease its dependence on imported gas (Joas et al. 2016). Internal to the electricity network security of supply is the effective coupling of supply and demand. Under the current paradigm of liberalised electricity markets, supply is largely driven by forecast demand over the short and long term, and by long-term predictions for infrastructure investment. Forecasting errors can result in affordability concerns. This can occur even in well-developed countries where planning processes are normally robust, as exemplified by the long-term forecasting difficulties in the Australian National Electricity Market, where the Australian Energy Market Operator has consistently overestimated demand since 2008 (Simshauser 2019).

\section{Resilience}

Definitions of resilience vary but, in the main, an electricity system is resilient when it is able to adjust to significant change and still maintain function. Engineers seek to design systems that are fail-safe, but the cost associated does not meet affordability requirements. Electricity systems are therefore designed to tolerate predictable faults, outages and weather events. This form of resilience can be thought of as engineering resilience, as it is the design of the system to adapt to predictable changes (Molyneaux et al. 2016). Energy system resilience requires the ability to adapt to more than technical faults and constraints. Unpredictable change may come in the form of higher global fuel prices, environmental policies or technological innovation. Examples of change pertinent to decarbonisation include carbon constraints or prices, a large take-up of air conditioning or electric vehicles and consumer investment in solar photovoltaic (PV) panels. Factors that are effective in improving energy system resilience include spare capacity in fuel sources, spare capacity in generation capacity and diversity in fuel sources for generation. Diversity in fuel sources is not simply a matter of pursuing strategy to encourage fuel switching, because fossil fuel prices are often correlated. For instance, in the USA in the 1970s, oil price escalation led to natural gas and coal price escalation, all of which led to electricity price escalation, which had severe consequences for manufacturing. Technologies that use solar, wind, geothermal and hydro resources are all independent of each other and fossil fuel prices, making a combination of these fuel sources highly desirable for energy system resilience. Systems that have more diverse fuel sources, reliant on unpredictable weather conditions, require interconnection and energy storage to secure supply from areas with different weather and demand patterns. Strategies of diversity and spare capacity require rules to direct planning, operation and actions by electricity sector participants. A lack of guidance by rule-makers will result in electricity systems vulnerable to a high dependence on any one fuel source because investors will seek the current cheapest technology. Fuel source diversity acts as insurance against future fuel shortages or escalating fuel prices to enhance system resilience and tariff certainty.

\section{Balancing Objectives}

Priorities shift as countries develop. In developing countries, access and affordability are prioritised above all objectives. As economies mature and industrial and commercial 
demand grows to underwrite the cost of electricity generation, priority shifts to security of supply. Industrialised countries' prioritisation of security of supply is related to the business imperative for secure, affordable supply to facilitate competitive advantage. In the development of policy frameworks for energy and climate, industry and business demands for affordable, secure supply have taken precedence over requirements for emissions reduction (Meadowcroft 2011). The discourse has not included the potential for future threats from carbon constraints or climate change. The challenge for policy frameworks is to prioritise the objectives of emissions reductions and resilience in the short term to gain energy security and affordability in the long term.

\subsubsection{Manufacturing, Construction and Mining Processes}

The manufacturing, construction and mining sectors release emissions through burning fuel for heating and cooling, through chemical reactions and from leaks from industrial processes or equipment. These sectors contribute $32 \%$ of GHGs and are discussed in more detail in Chapters 16, 12 and 20, respectively. Decarbonisation of electricity supply, either by on-site generation or access to grid power from renewable resources, can reduce manufacturing emissions. In the longer term, the replacement of gas for industrial processes may be possible, using concentrated solar thermal in some locations or hydrogen and its derivatives. The sector chapters also emphasise the potential for improved energy efficiency that can reduce energy consumption and costs. The possible emergence of direct reduction of metal ores with renewable energy utilising 'green' hydrogen (produced by water splitting) could have highly favourable prospects for some economies while reducing emissions. A resurgence in mining based on the raw materials needed for modern technologies such as lithium is predicted. Such mining would desirably be as carbon-free as possible, notably through renewals-based electrification. Material switching, such as to more wood in construction and to new technologies to replace Portland cement, also hold promise for emissions reduction in construction.

For detail on the technology options for these sectors, readers should turn to the appropriate chapters. Climate policy for these sectors is subject to a different set of complexities to those encountered in the electricity supply industry.

\subsubsection{Complexity of Global Competitiveness}

The post-war rise of Japan as a global manufacturer initiated intense international competition to supply product to the world's consumers. The growth of new manufacturing sectors required low production costs. In this tightly contested space, national industries that are large employers seek preferential treatment to facilitate global competitiveness through reduced taxation, removal of international tariff barriers and forgiveness from climate policy costs. An unintended consequence of the Kyoto Protocol's focus on equity for developing nations is carbon subsidies for internationally traded goods. For a detailed discussion on the challenges of integrating climate change policy with international trade, refer to Chapter 21. 


\subsubsection{Complexity in Assigning Responsibility for International Emissions}

As China has developed to be the world's pre-eminent manufacturer, it has become the world's largest GHG emitter. Much of China's production (along with other developing nations in Asia) is exported without transfer of responsibility to the consuming nation for the GHG emissions embodied in the products. Marine and air transports consume fossil fuels that emit GHGs in international waters and space, but are not accounted for in national inventories or targets. These result in inaccurate accounting for GHG emissions and increase the complexity of policy to reduce emissions at a national level.

The original framework envisaged in the Kyoto Protocol included the concept of internationally linked emissions trading schemes incorporating flexible mechanisms like the Clean Development Mechanism (CDM). These schemes were aimed at encouraging cross-border emissions trading and developed countries' investment in developing countries' emissions reduction projects in order to meet national emissions reduction targets. The complexity of establishing global mechanisms of this nature has inhibited their potential.

\subsubsection{Mining and the Resource Curse}

The resource curse is frequently associated with the unexpected economic disadvantage that results from the development of lucrative extractive industries. It is primarily expected in developing countries, which lack the institutional, legal and political infrastructure to protect against political capture by extractive industries to the detriment of other sectors of the economy (Sachs and Warner 1997; Barbier 2003). Developed countries may, however, also fall prey to another aspect of the resource curse, known as 'Dutch disease'. In this form of the malaise, the extractive industries drive rising exchange rates that render manufacturing or agricultural products less competitive internationally. Examples of Dutch disease include the impact of natural gas exports on the Netherlands in the 1960s, North Sea oil on the United Kingdom in the 1980s and coal and natural gas exports on Australia from the mid-2000s (Goodman 2008).

The prospect of reduced coal, natural gas or oil extraction to mitigate against climate change is particularly challenging for national and subnational states already experiencing the consequences of the resource curse or Dutch disease. These states may be particularly constrained from restructuring due to heavy reliance on the proceeds and employment from fossil fuel mining (Goodman 2008; Jakob and Steckel 2014; Baer 2016).

\subsubsection{Transport}

Motor vehicles, aircraft and marine vessels release emissions through burning fuel. In transport as in manufacturing and processing, electrification and other fuel switching - to hydrogen fuel cell or synthetic fuels - are key strategies for emissions reduction for passenger cars and road freight. Challenges are posed in the aviation and marine transport sectors but electric and hybrid aeroplanes are already in development. Chapter 15 emphasises the desirability of lifestyle adjustments with the related changes to cityscapes to 
encourage bicycling and walking. The advantages of compact cities are emphasised in Chapter 11.

Climate policy to address emissions in transport tends to rely heavily on innovations; for example, electric vehicles or hydrogen fuel cell vehicles. There are however multiple opportunities for emissions reduction from investing in public transport and encouraging greater use of public transport. Also, shared vehicle ownership presents opportunities for significant emissions reductions. Further discussion on this can be found in the chapters on transport and cities.

\subsection{Developing Coherent Policy Frameworks for Decarbonisation}

At the highest level, a robust array of non-political meta-governance and governance structures is required to facilitate the transformation of the energy sector to new lowcarbon technologies. This integration of new and existing institutional structures to support decarbonisation is critical to ensure effective implementation and acceptance of policy pathways. To facilitate the ability to adapt, rules should avoid being prescriptive and planning needs to place the highest priority on decarbonisation options.

\subsubsection{Creating Incentives for Investment}

\subsubsection{Pricing Carbon}

Economists have long argued that market-related polices will be the most efficient mechanism for influencing investment decisions. Currently, low-carbon plant and industrial processes are more expensive than existing plant and processes reliant on fossil fuels because there are no costs associated with carbon emissions. Pricing of carbon emissions creates behavioural change by consumers, which leads to reduced consumption of plant and processes reliant on fossil fuels.

Pricing can take the form of a carbon tax (CT) or the trading of permits to emit carbon through an Emissions Trading System (ETS). With a CT, the state or regulator decides on the price of emissions and emitters pay the state for emissions generated. With an ETS, the state or regulator decides on the reductions in emissions over a specified time period, and then auctions the available stock of emissions for emitters to purchase to meet their liability. Penalties result if emitters emit more than the quantity of permits purchased.

There are multiple implementations of both ETSs and CTs around the world, but in the main ETSs have struggled to achieve significant emissions reductions because of difficulties in predicting appropriate emissions targets without compromising national economies. The surplus supply of permits leads to permit prices too low to induce investment. Carbon taxes have also not been very successful, due to political concerns and public antipathy to taxation and increasing tariffs.

Australia's climate policy provides an illustration of the difficulties of implementing carbon prices. There have been two attempts at pricing carbon. In 2009, the Carbon Pollution Reduction Scheme (CPRS), effectively an ETS, was introduced and passed in 
the House of Representatives but failed multiple times in the Senate. As a result of the divisive debate around climate policy, Malcolm Turnbull, the leader of the Opposition Liberal-National Coalition, lost the leadership to Tony Abbott. Because of falling popularity as a result of multiple issues, but including climate policy, Kevin Rudd, the Prime Minister, lost the leadership of the Australian Labor Party to Julia Gillard. In 2011, Julia Gillard's government passed the Securing a clean energy future: Implementing the Australian Government's climate change plan, which included a CT for top polluters from 1 July 2012 until 30 June 2015, transforming to an ETS, with 50\% of permits purchased from domestic sources, and a price ceiling and floor for the first 3 years. Tony Abbott, reflecting the view of some sectors, called carbon pricing 'a so-called market in the nondelivery of an invisible substance to no-one' (Metherell and Hawley 2013) and claimed: 'The thing about the carbon tax is that it will clean out people's wallets and it will wipe out jobs big time.' (Parliament of Australia 2011: 10990). At the next election, the LiberalNational Coalition won government. Tony Abbott had campaigned using the slogan 'Axe the Tax', and repealed the Clean Energy Legislation in 2014.

Key areas to consider when implementing pricing mechanisms are: who sets long- and shortterm target reduction or carbon price; what sectors to include; how to educate the public and how to reduce political interference with respect to setting the cap or the tax.

\subsubsection{Feed-In Tariffs}

Many countries have pursued feed-in tariffs (FITs) as a means to incentivise investment in RE. The most successful country in this regard has been Germany. Certainty for investors was gained through prioritised access to the electricity grid for RE generators and fixed tariffs for RE owners. Investment in RE from private citizens, farmers and cooperative programmes has contributed to broad public support for RE projects. After investment in 38-GW (gigawatt) wind and 40.5-GW PV panels between 2002 and 2016, there is debate about the cost of that incentive scheme to German consumers. For now, it appears that the majority of consumers are not unhappy with significant investment in energy from wind and sunshine (German AEE 2019), and the manufacturing capacity to sustain that investment. Germany continues to encourage investment in RE, although FITs are now only available for small installations and are adjusted in line with achievement of targets to avoid large overshoots in investment like those experienced in 2010-11. For larger installations, an auction mechanism for tariffs dictates investment decisions. Feed-in tariffs have been successful at incentivising investment in RE although there are questions around the cost associated with this policy mechanism.

Key areas to consider when implementing FITs are: who sets long- and short-term FITs; how to ensure flexibility in FITs to reflect achievement of targets; how to ensure FITs don't produce regressive outcomes that drive inequity among households. 


\subsubsection{Regulating Renewable Energy Targets}

Some countries have avoided the political challenges of pricing carbon, and the costs associated with FITs, and have regulated to ensure that desired renewable energy targets (RETs) are met. These policies have been popular in the USA and Australia because although they are not perceived to be economically efficient, they don't require significant government intervention, and are in line the public's preferences for RE.

Responsibilities for the institutional framework include: the establishment of rules associated with eligibility of sources to qualify as generators of electricity from RE; the establishment of rules associated with the surrender of certificates by liable entities to meet the RE target; the issue of tradable certificates to RE generators for the electricity produced; and the management of the surrendered tradable certificates against the liability of wholesale purchasers of electricity.

While Australia does have a federal RET scheme, it has been subjected to a fractious political debate and a review that stifled investment for more than a year, and culminated in a reduced target in 2015. Responding to public preferences for RE, many state governments have announced RETs independent of the federal scheme.

Key areas to consider when implementing RETs include: who sets long- and short-term targets; how to reduce political interference in the setting of targets and how to encourage regionalisation of targets for geographical spread and security of supply.

\subsubsection{Support for Financing}

An overarching challenge in the deployment of low-carbon plants and processes is in accessing appropriate finance. Low-carbon plants are typically characterised by large, upfront capital costs and relatively low operational expenses when compared with more traditional supply technologies. Due to a lack of familiarity with the characteristics of low-carbon investment, perceived and actual finance risks are high. In recognition of this information gap, development banks are established to invest in low-carbon projects deemed too risky for traditional financing institutions. Examples include the Green Investment Group (GIG) in the UK and the Clean Energy Finance Corporation (CEFC) in Australia. Funds sourced from these institutions help to lower the cost of capital for new energy-related technology and improve incentives for investment in decarbonisation.

Originating as state-based institutions subject to revision in ownership, scope and focus, these low-carbon development banks can be hampered by the ideological and technological preferences of the incumbent political parties. Australia's CEFC has periodically faced pressure by politicians to reassign its mandate and enable investment in coal plants (Chan 2017; Coorey 2019). The UK's GIG originated as the Green Investment Bank (GIB) in 2012 but was sold to the Australia-based Macquarie Group in 2017, which may have altered its appetite for risk and investment in decarbonising technologies (UK GIG 2019: 3). 
Key areas to consider when establishing financing support include: coordination with institutions tasked with decarbonisation responsibilities to develop products suitable to meet targets; and the implementation of strategies to reduce political interference in development bank mandates.

\subsubsection{Facilitating Financing from Novel Sources}

Significant support for investment in low-carbon technologies in the community and business sectors in the USA, Europe and Australia has harnessed funds from a broad spectrum of small to large investors. Indeed, community financing in Germany and Denmark has done much of the heavy lifting of investment in RE in those countries. Where individuals within a community decide to invest in RE as a cooperative venture, investment may be made by local private investors on a for- or not-for-profit basis. Returns for investment can be delivered to investors through: credits to investors' electricity bills; proportionate income from sales of electricity; proportionate income from sales of RE certificates if the country where the investment is made has some form of RE target; or a combination of the above. In the USA, where there is the potential for the application of investment tax credits (ITCs) to earnings, the business structure of the community entity can improve returns by reducing income tax liability. Consequently, there are numerous combinations of investor structures and business models in the USA to maximise returns. Institutional frameworks for community RE investment need to ensure that electricity rules allow: access to the grid and provide rules for the flow of returns to the investors from retailers or generators; that investment rules accommodate groups of small investors who seek to fund RE; and that, where applicable, tax incentives are transparent.

Crowdfunding, defined as 'the collective effort by people who network and pool their money together, usually via the internet, in order to invest in and support efforts initiated by other people or organizations' (Ordanini et al. 2011), is a novel business model which has the potential to tap into small investors with interests in RE and could result in disruption in both the energy and financial sectors. There has been some formalisation of the institutional structure, along the lines of the Jumpstart Our Business Start-ups (JOBS) Act in the USA ${ }^{2}$ to legalise certain forms of equity crowdfunding. Australia has also legislated to facilitate crowdfunding (Parliament of Australia 2016) while seeking to protect small, immature investors.

Corporate power purchase agreements (PPAs) are a further novel approach to underwriting investment in RE. Where large commercial energy users seek to hedge against increasing power prices, long-term (anywhere from 10 to 25 years) PPAs are signed. A recent focus has been for large corporations to sign PPAs for RE to underwrite project investment.

\footnotetext{
2 Jumpstart Our Business Startups Act, Pub L No 112-106, 126 Stat 306 (2012). Available at: www.govtrack.us/congress/bills/ $112 / \mathrm{hr} 3606 /$ text.
} 


\subsubsection{Regulating Options for Renewal of Ageing Electricity Generation Fleets}

The investment in coal-fired power from the mid-1970s to 1980s has resulted in coal generator fleets now ready for replacement in the USA, Europe and Australia. The US Clean Power Plan (CPP), announced in 2015, set emissions benchmarks for power stations too low for the operation of coal-fired power stations (US EPA 2015). The CPP never took effect (Scobie 2016) but the low price of natural gas and RE, and the intention of the CPP, resulted in reduced coal plant capacity as retiring plants were replaced by lower emitting plants as shown in Figure 1.2.

A $15 \%$ reduction in carbon dioxide $\left(\mathrm{CO}_{2}\right)$ emissions from electricity generation was achieved from 2014 to 2017 through this fleet renewal process, as seen in Figure 1.3. The legal challenge to and repeal of the CPP, and instatement of the Affordable Clean Energy (ACE) rule on 19 June 2019 (US EPA 2019), which relaxed limits on GHGs from power plants, halted emissions reductions.

China too has pursued efficiency gains through fleet renewal. In the 'large substitute for small' programme, $76.8 \mathrm{GW}$ of small inefficient coal plants were decommissioned and replaced by large efficient plants (IEA 2014). Nevertheless, while efficiency programmes have slowed China's growth in carbon emissions, it has not facilitated any absolute decline in them. With a relatively young coal power fleet (the average age of the coal fleet is 11.1

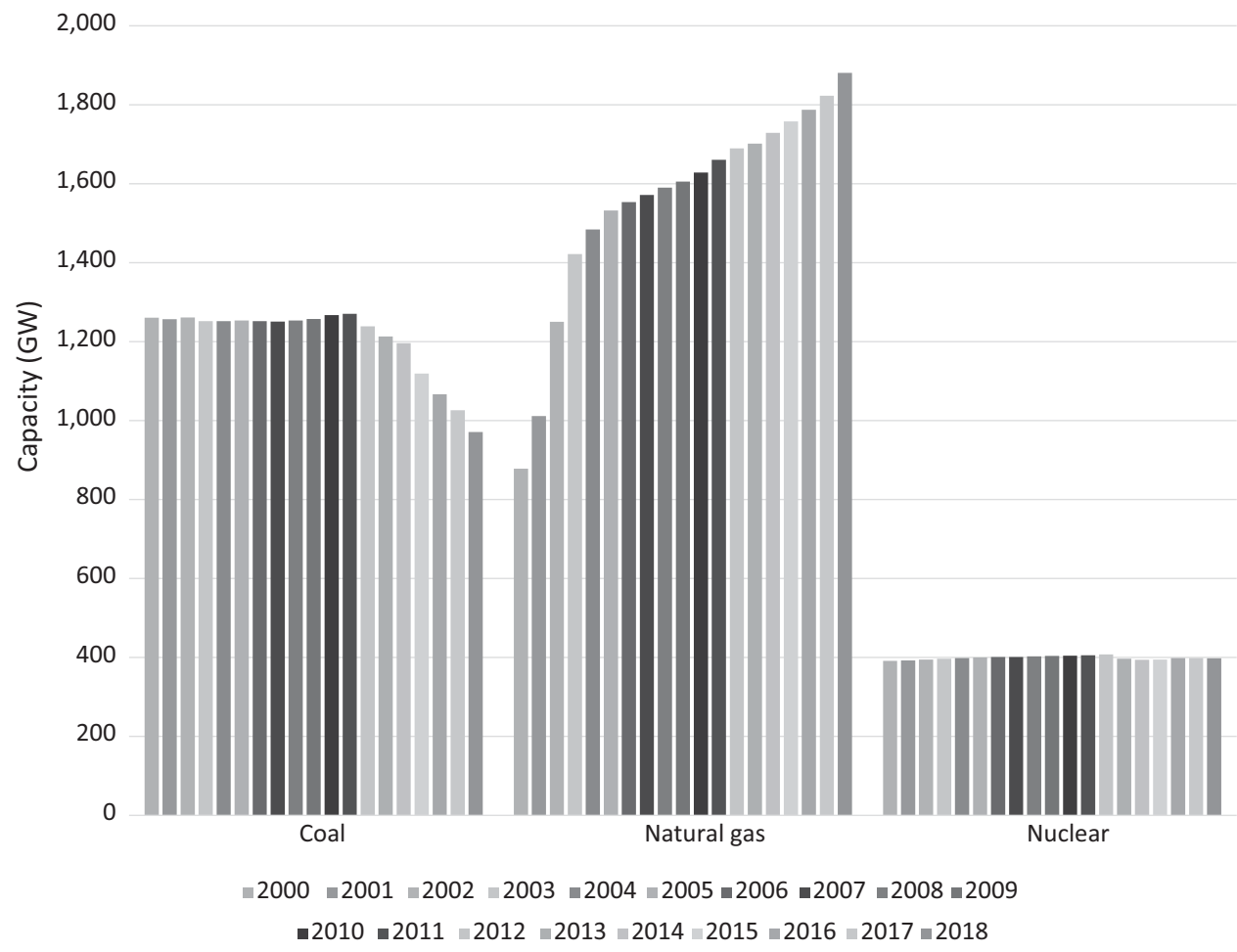

Figure 1.2 US generator capacity by fossil fuel source.

Source: US EIA (2019a). For a colour version of this figure, please see the colour plate section. 


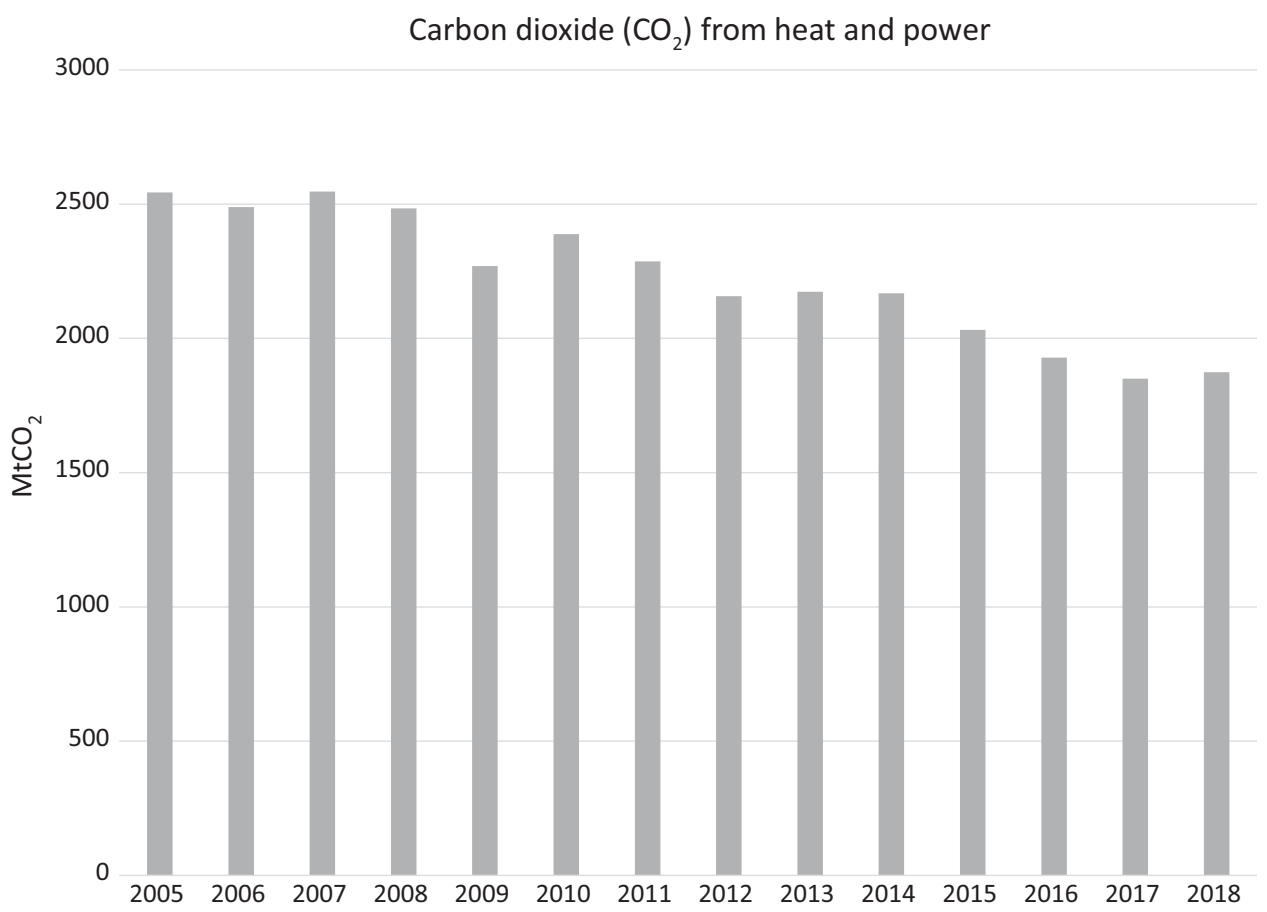

Figure 1.3 $\mathrm{US} \mathrm{CO}_{2}$ emissions from power generation.

Source: US EIA (2019b).

years (Tong et al. 2019)), there is now less opportunity to reap efficiency gains and emissions reductions from plant renewals.

Efficiency gains and fuel switching are positive outcomes but decarbonisation requires a faster transition than a simple switch between fossil fuels. Figure 1.4 shows the extraordinary challenge required of China if the world is to limit $\mathrm{CO}_{2}$ emissions and contain the consequences of climate change as modelled by the IEA.

Key areas to consider when regulating fleet renewal include: coordination with institutions tasked with decarbonisation responsibilities to develop suitable targets associated with fleet renewal.

\subsubsection{Developing New Industries That Advance Decarbonisation}

While the price of low-carbon technologies may have reduced dramatically over the last decade, there is still a view that market forces alone will not be able to drive the implementation of these technologies and industries at the rate required for decarbonisation. For this reason there is still a significant role for the state in supporting low-carbon industries to facilitate the growth of low-carbon economies (Moe 2010). 


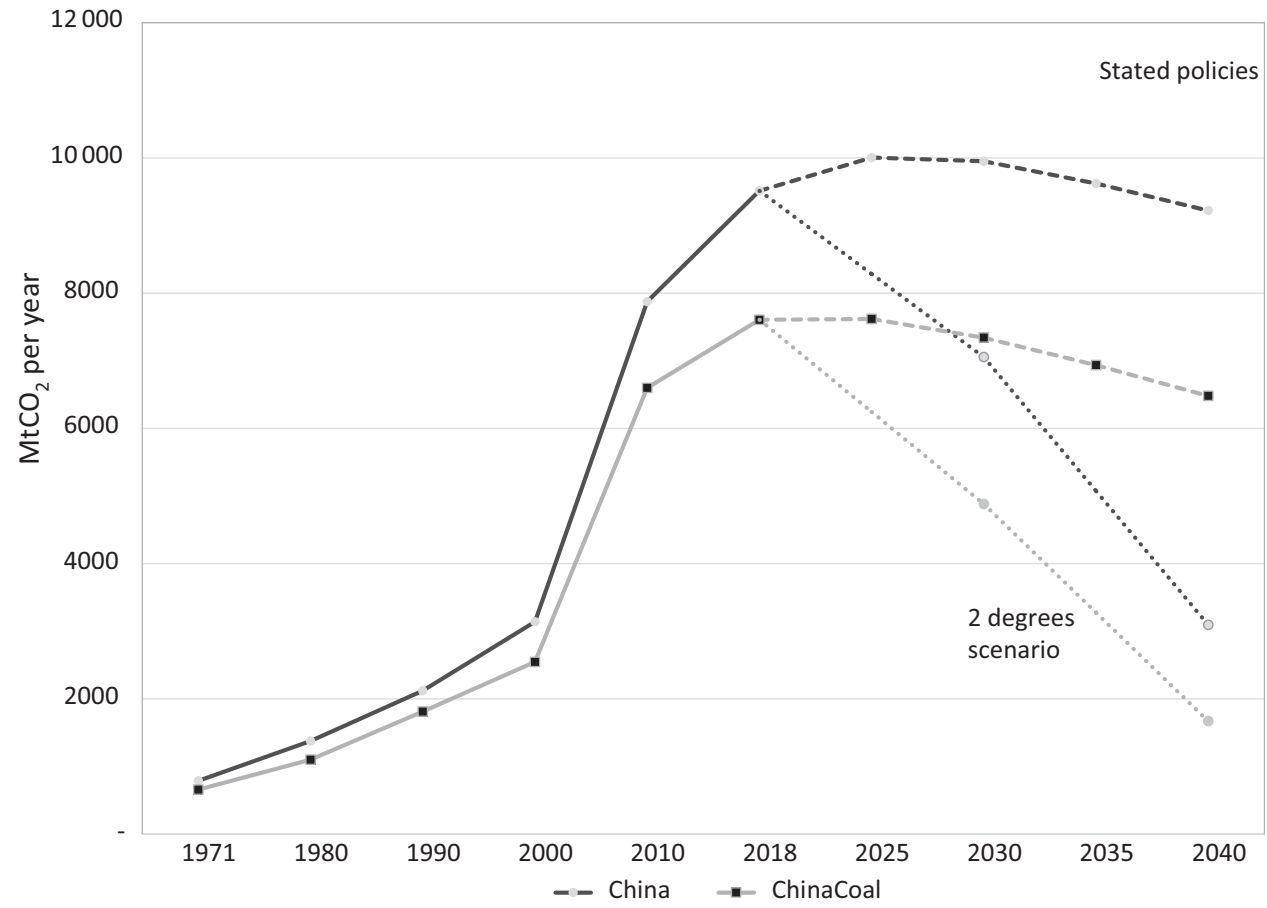

Figure 1.4 China $\mathrm{CO}_{2}$ emissions from energy combustion: actuals 1970-2018 and projections 2025-2040. Note, the dashed lines show projections of emissions based on current stated policies. Dotted lines show projections of emissions based on policies required to limit global warming to below $2{ }^{\circ} \mathrm{C}$.

Sources: IEA (2019b, 2019c, 2019d).

France, Germany and Denmark provide excellent examples of the development benefits of advancing investment in decarbonisation technology. In France's case, a nuclear power industry grew out of a regulated response to energy security in the 1970s, which created employment and in turn facilitated exports through the application of knowledge gained in the process of nuclear deployment to international projects. In Denmark's case, a wind power industry grew out of carbon price and FITs to foster energy self-sufficiency, created employment and in turn facilitated exports through the manufacture and deployment of new technology. In Germany's case, a PV industry grew out of FITs in response to a requirement for decarbonisation and energy security, which created employment and in turn facilitated exports through the manufacture and deployment of new technology in Europe. The European Commission also took the opportunity to boost economic recovery and GHG reductions by funding the European Energy Programme for Recovery in 2009, in the wake of the financing constraints that followed the Lehman Brothers collapse (European Commission 2009).

\subsubsection{Research into New Technology}

Institutions that facilitate research remain the best mechanism for incentivising greater levels of research into new electricity system-related technology. After the global financial 
crisis in 2008, the US government made available USD 1.5 billion in research funding for energy storage to benefit both the US motor vehicle sector and the electricity sector. Germany, in its 6th Energy Research Programme, allocated approximately EUR 3.5 billion for funding the research and development of energy technologies between 2011 and 2014 . Other countries make available public money for research in universities and technical institutions. Australia established the Australian Renewable Energy Agency in 2011 for seed funding for new and promising technologies, although from 2014 its funding has been progressively eroded to alleviate government budget constraints (St John 2016). Government commitment to funding of appropriate research into energy technologies remains an important pathway to rapid decarbonisation but there has to be the political will to adequately fund research, and public support for the funding to be made available.

Key areas to consider when allocating funds for research include: funding allocation mechanisms and how to raise adequate funding for research.

\subsubsection{Creating Incentives to Change Consumer Behaviour}

\subsubsection{Efficiency}

Market, information, organisational and institutional failures have led to firms operating at suboptimal energy efficiency levels. Unexploited potential energy efficiencies are often referred to as the 'energy efficiency gap' (Hirst and Brown 1990). There are several reasons for this seemingly irrational behaviour, but the most common include market failures and barriers like: shareholder expectations with respect to returns, which constrain investment in energy efficiency; low priority of energy issues, which leads to inadequate skills within firms to identify opportunities or keep up with innovations; and subsidies and unpriced costs such as air pollution (Brown and Sovacool 2011). Increasing efficiency in electricity consumption reduces demand for electricity and thus in the investment required for decarbonisation, suggesting an important role for government intervention.

Studies point to significant energy consumption reduction by relatively small changes to behaviour and investment. This is discussed in detail in the industry chapter (Chapter 16) but, in summary: new buildings can be designed and existing buildings retrofitted for greater energy efficiency; energy efficiency can be engineered into industrial processes and investment in LED (light-emitting diode) lighting and combined heat and power can reduce electricity demand.

Efficiency programmes assist companies to identify and implement energy efficiency opportunities. Of these programmes the following are amongst the most effective:

\section{Energy Price Increases}

In line with economic theory, an increase in price decreases consumption, theoretically through energy efficiency measures taken to counteract increases in energy costs. It has 
been estimated that, in China, electricity tariff subsidies have led to heightened electricity consumption (IEA 2014). If subsidies were removed, efficiency measures would follow (Wang and Lin 2017). A study of industrial electricity consumption in South Korea found that electricity reductions of between $1.3 \%$ and $10.5 \%$ (depending on the price elasticity of demand) could be achieved by increasing the electricity price to average Organisation for Economic Co-operation and Development (OECD) levels (Han and Yun 2015).

While price may be the most effective tool for improving efficiency, it is not popular with consumers and causes problems for politicians. Since 2007, electricity prices in Australia have increased significantly, driven initially and primarily by heavy investment in networks, but also by FITs, the CT and larger profits for retailers. These increases have helped reduce consumption but have been extremely unpopular. Price increases in Britain since 2003 have also led to reductions in electricity consumption but the price rises have been accompanied by public distrust of energy companies.

\section{Energy Efficiency Standards}

Energy efficiency standards for buildings, transport vehicles, and energy-using industrial equipment and appliances play a significant role in improving energy efficiency, providing a clear role for governments to intervene. There are, broadly, two important approaches: minimum energy performance standards and top-runner or best available technology standards. Both provide incentives for the ratcheting up of energy efficiency performance standards. These are further discussed in the industry chapter (Chapter 16).

\section{White Certificate Schemes}

White certificates are used to certify energy reduction attained. Under these schemes, firms producing, supplying or distributing oil, gas or electricity are required to use measures to achieve predefined energy efficiency levels. If defined targets are not met, penalties are incurred. Certificates are issued to the entity on receipt of evidence of energy savings. In most of these schemes, certificates can be traded or used to meet energy-saving obligations.

\subsubsection{Demand Management}

It is estimated that demand-side initiatives could save AUD 4-12 billion over 10 years in Australia (AEMC 2012), with associated emissions abatement. The most powerful of demand response tools is time-of-use (TOU) tariffs for electricity. With the increasing concentration of electric goods in homes, residential demand has increased relative to commercial and industrial demand such that peaks in electricity demand occur during the late afternoon and early evening. Time-of-use tariffs reflect the cost of delivering electricity when demand is increased but require advanced metering infrastructure to record electricity consumption so that tariffs can be applied appropriately. Where new meters and tariffs are implemented and consumers are not advised about the costs, benefits and required behaviour change, consumer anger can result, as was the Victorian experience in Australia (King 2015). 


\subsubsection{Communicating Benefits of Low-Emission Options to the Public}

With large centralised generation and networks for distribution dominating existing electricity sector technology, it is imperative for the public to be informed about the potential for new technologies and the benefits experienced from policy action. Good policy frameworks should include funding for government agencies that are able to communicate with the public. In Australia, the Australian Renewable Energy Agency (ARENA) is tasked with that responsibility, while globally the International Renewable Energy Agency (IRENA), the International Atomic Energy Agency (IAEA) and the Global Carbon Capture and Storage Institute (GCCSI) all participate with the International Energy Agency (IEA) as intergovernmental agencies tasked with communicating the benefits of low-emission options to the public.

In support of its energy transition policy ('Energiewende'), Germany has several additional research and policy institutes that conduct research into, and communicate, the potential and outcomes of decarbonisation policies. Examples include: the Fraunhofer Institute, which has published research findings on the cost benefits of RE policies in Germany (German BMU 2009) and facts about photovoltaics in Germany (Wirth 2017); the Renewable Energies Agency, which has published findings on public acceptance of RE in Germany (German AEE 2016, 2019); and the German Aerospace Centre, which has published research on possible energy system scenarios for Germany (Pregger et al. 2013) and, in collaboration with Australian researchers, has published on how climate targets can be achieved (Teske 2019).

\subsubsection{Adapting Institutional Frameworks}

\subsubsection{Requirements for a Decarbonisation Framework for Liberalised Electricity Systems}

Merit order dispatch and wholesale electricity markets have evolved to discover lowestcost generation of energy from fossil fuels. The arrival of new technologies has highlighted the inadequacies of markets established purely for the dispatch of fossil fuels. Renewable energy has no or very low marginal costs and thus is dispatched in preference to energy generated from fossil fuels, which creates technical problems for generators that have mustrun properties. Distributed generation in the form of rooftop solar panels needs to be integrated into the electricity market and yet each household/consumer is too small to participate in an electricity market. With this level of change facing the electricity sector, there have been questions raised as to the efficacy of electricity markets to deliver investment and integration of new technologies with different characteristics into a decarbonised electricity sector (UK CCC 2009; Rhys 2010; Thomas 2016). Some jurisdictions have already initiated changes. Germany's FIT legislation provided preferential dispatch and fixed-term contracts for RE generators in 1991. Britain's Energy Act 2013 tasked OFGEM with establishing long-term contracts for difference (CFDs) to provide stable returns for investment in low-carbon generation, to provide a capacity market for supply security and to ensure the availability of long-term contracts for independent RE generators (Thomas 
2016). The state of South Australia has declared an intention to commission investment to counteract the shortcomings of the electricity market and federal energy policy which have resulted in reduced grid stability from high levels of generation from wind and solar power in that state (AAP 2017).

As an alternative to increasingly complex market manipulations, one proposal suggests a central agency to take responsibility for delivering both the low-carbon emissions target and adequate investment in infrastructure (Rhys 2010, 2014). As there is no or low marginal cost associated with low-carbon electricity, the concept of a central buyer tasked with awarding preferential supply arrangements at project sign-off through an auction mechanism to guarantee competition among technologies, abatement and investors, has its merits. German investment in large-scale RE is currently awarded using this framework. As variable and intermittent sources of energy supply higher proportions of electricity, backup reserve, supply balancing and demand response assume higher importance in securing supply. Firm capacity markets (as being discussed in Europe) (Eurelectric 2015), balancing markets (as being pursued by the western USA) (Lenhart et al. 2016) and demand response markets (Wang and Brown, 2014; Mahmoudi et al. 2017) therefore should be developed to replace or evolve from more traditional wholesale markets to become the primary short- and medium-term market mechanisms to respond to supply gaps, voltage instability or demand fluctuations.

There have been calls for more inclusive network planning frameworks to replace traditional processes. One of the key areas that has gained traction is integrated resources planning (Tellus 2000), which takes a holistic approach incorporating both supply- and demand-side options. By internalising the consideration of demand-side options, this process allows for the incorporation of environmental and social objectives, while potentially promoting more cost-effective network solutions. These gains are achievable due to greater contestability of service provision. There has been considerable work done to date on the development of these processes in markets such as California (CPUC 2019), Australia (AEMO 2019) and the UK (UK OFGEM 2016).

\subsubsection{Requirements for Regulated Vertically Integrated Electricity Sectors}

Without the complexity of governance and operation of liberalised electricity systems, decarbonisation requirements can be regulated and the vertically integrated electricity sector can be required to comply with decarbonisation goals. A good example of decarbonisation achieved through regulated vertically integrated electricity systems is the decision by France taken in the 1970 s to deploy nuclear power. While many other nations were considering the benefits of nuclear power in the late 1960s and 1970s, none other than France was able to implement a wholescale transformation of the electricity sector. What facilitated France's transition was a combination of political will, informed by a highly technocratic and powerful administrative system, effectively executed through the Ministry of Industry, which was responsible for both the atomic regulatory body and the state-owned power utility. What was particularly significant was that despite a lack of bipartisanship on the benefits of nuclear power during elections, French presidents from both sides of the 
political spectrum continued deployment after being elected. The French approach to the politics of nuclear power deployment differed remarkably from the USA, where a noninterventionist, free market approach ensured that policies were more concerned with formalistic regulatory management of utilities 'from the outside' with little ability to 'impose its will on a myriad of electric utilities' (Jasper 2014). The French example indicates that there are benefits to vertically integrated, publicly managed institutional frameworks when considering decarbonisation of the electricity sector.

\subsubsection{New Models for Remote Regions}

Access to electricity remains a challenge for remote regions for a variety of reasons, including the cost of infrastructure required to supply to remote locations, the ability of consumers to pay for electricity and the industrial demand to underwrite the cost for residential and small business consumers. Models for electrification in remote regions are emerging and reflect the context of electricity provision for agrarian villagers with little ability to pay for electricity.

Addressing energy poverty in rural areas therefore requires subsidisation, new micropayment models, and local RE generated for village microgrids, without a requirement for a developed country-style liberalised electricity market. Funding for the capital investment needs to come from investors in microfinance, development, aid and industries aligned with remote locations like mobile telephony and information technology, because income in remote rural areas is insufficient to pay for large infrastructure. In pursuit of the roadmap to achieve decarbonisation while enhancing productivity and jobs growth, the deployment of village-based electricity infrastructure using the investment models mentioned above can encourage the creation of jobs to support and administer the systems within the remote areas themselves, and in so doing creates an industry sector alongside the electrification programme. This removes the binary nature of options for rural electrification - of either emissions from electricity generation or no electricity access - and thus reduces the tensions between sociopolitical objectives.

The institutional framework for rural electrification therefore requires structures or agencies to identify: demand for electrification; supply of different classes of investors and funds; appropriate technologies and sources of RE; business models for implementation; operational support and administration requirements; and training opportunities for local individuals to be able to operate and support business models.

\subsubsection{Addressing the Inconsistencies in International Accounting and Responsibility for Carbon Emissions}

The Kyoto Protocol was created as a framework of consensus on the individual ability of nations to achieve emissions reductions. It has not been successful. This does not mean that individual countries seeking to act decisively should not continue to implement climate policy that is cognisant of the risks of climate change. Indeed, the EU has taken such a 
stance, seeking much greater carbon emissions reductions than other nation states or economic blocs, in line with their concerns about the consequences of climate change. This is discussed in detail in Chapter 21 but, in summary, the inconsistencies that arise from uneven action to address carbon emissions can be addressed by nation states or economic blocs through border adjustments and trade agreements that account for the costs of embedded carbon content. This is not a perfect outcome, but it does help to advance emissions reductions as nation states are subjected to the political exigencies associated with their responsibilities to reduce emissions.

\subsection{The Challenges to Confront}

We have discussed the linkages between broad policy objectives and the instruments used to implement those objectives. We have explicitly recognised the importance of the contextual environment for the formation of new industrial configurations which are enabled through the emergence of new technologies. We will now explore the current challenges being presented to institutional environments as a result of new technologies aimed at decarbonisation.

\subsubsection{Integrating the Old and the New}

The management of the transition from centralised to decentralised systems is challenging. It requires careful and pragmatic planning and management of the grid. The German grid operators have found that improved weather forecasting has significantly improved the management of fast shifts in supply. The Australian Energy Market Operator has found that the ability to direct centralised generators to supply in times of supply constraint is more effective than awaiting market offers for supply. The overarching requirement though is for grid and market operators to proactively forecast, plan and manage according to the situation at hand. A prescriptive rule-based electricity sector will not be adaptive nor will it deliver a secure supply of electricity.

Decarbonisation and supply security are public concerns and if tariffs are to be kept affordable then incumbents will need to be supported through the transition. Managing incumbents will be as much about end-of-life asset management and integration with new technologies as it will be about designing markets to ensure that there is sufficient competition amongst incumbents to reduce rent-seeking behaviour.

The consensus on the need for action that emerged from the 2015 United Nations Conference of the Parties (COP 21) has set a level of expectation that action at all levels of society is necessary. It is noteworthy that some business and private actors are now acting independently of regulatory frameworks on mechanisms like corporate PPAs, direct investment in RE and new funding mechanisms. There is a role for investment to proceed outside of current mechanisms and regulation to pursue decarbonisation. Facilitating the ability of investors and system managers to operate independently of regulatory frameworks will significantly enhance the adaptation of the system. 
Key areas to consider when integrating the old and the new are: management of variable supply and demand; and coordinating market structures.

\subsubsection{Managing the Politics}

There are 'boundaries to economic rationality and calculation, so that the latter are allowed to operate only in certain circumstances. The most precise methods for making policy recommendations eventually run into the realities of political resistance and conflict' (Jasper 2014: 3).

And yet it is important to remember that history shows 'only states that managed to prevent vested interests from gaining control over economic policy-making stood much chance of pursuing policies of structural change' (Moe 2010).

\subsubsection{Political Involvement}

Despite the complexity of the decisions facing politicians, there is evidence of political roadblocks being applied to climate policies (Bayulgen and Ladewig 2017). These political roadblocks in the USA reflect historic tepid public mood on the need for climate policy action (at about 50\% support) (Pew Research Center 2016). In Australia, only 55\% of Australians think that governments are not doing enough on climate change, although there are significant differences across the political spectrum (Merzian et al. 2019). Overcoming political obstacles to decarbonisation needs a combination of determination, persuasion and horse-trading between political actors (Compston and Bailey 2012) to convince a sceptical public of the long-term benefits.

\subsubsection{Lessons from Historical Roll-Outs of New Technology}

There are a number of lessons to be learned from the institutional frameworks that facilitated the roll-out of nuclear power in France and curtailed it in the USA in the 1970s. Of importance here is that US politicians used their ideological frameworks to twist the energy policy debate and frame it as a free market versus government intervention decision (Jasper 2014). The US predisposition towards free market ideology burdened potential investors and financiers with significant risks associated with the choice of technology, the costs of operation and waste disposal, public resistance and public safety in the event of accidents. These were too large to attract significant levels of investment in the US nuclear power industry. By comparison, the French state assumed responsibility for these risks and thus formulated energy policy which drove strategic state objectives of energy security despite public resistance.

By comparison, Germany has a history of strong and effective policy frameworks to secure environmental benefits by pursuing technologies rather than ideologies. In 1983, regulation to limit emissions of sulphur dioxide $\left(\mathrm{SO}_{2}\right)$ from all power stations through the implementation of flue gas desulphurisation technology, despite concerns raised by industry, electricity and coal-mining sectors, achieved 93\% reduction in emissions within 12 
years, faster and more effectively than the cap-and-trade policy mechanism employed in the USA, which achieved a 51\% reduction in emissions from 1995 to 2010 (Harrington et al. 2004). Legislation to encourage investment in new technology since 1991 has had consistent bipartisan support resulting in significant investment. Initial responsibility for RE policy was assigned to the ministry of the environment, which avoided confrontation with industry actors with political power and contrasting priorities. Jobs created in the RE sector tended to be in small- and medium-sized enterprises and in regions that were rural or economically less developed. Coupled with RE investors, which included private citizens, farmers and cooperative programmes, this technology-led approach helped to create a positive view of the benefits of RE and public support for the decarbonisation framework.

The lesson from the politics of nuclear power in France and the USA, and the technocratic approaches preferred in France and Germany, is that political ideological world views should be removed from the formulation of policy frameworks.

\subsubsection{Lessons on Gaining Independence from Political Interference}

To illustrate the advantages of institutional frameworks that seek independence from politics, it is pertinent to look to the frameworks that emerged after the damaging levels of inflation created during the 1970s and 1980s. In many jurisdictions, national reserve banks have been given the independence and responsibility to direct monetary policy to seek financial system stability, currency stability, full employment and economic prosperity. These objectives allowed technocrats in national reserve banks, removed from politics, to focus on long-term economic growth and politicians in national governments to accept responsibility for disciplined fiscal policy to achieve medium-term stability (Reserve Bank of Australia 2013).

A similar structure may be beneficial for decarbonisation. A Climate Change Authority (CCA) was established in Australia in 2011 but not endowed with the responsibility to manage the achievement of targets. Consequently, it was perceived more as an advocate of climate policy than as the body responsible for achieving targets. For effective pathways and roadmaps to decarbonisation, an independent authority, populated with technocrats, could be given the responsibility to meet a long-term decarbonisation goal. The most effective tools would be applied to meet that goal, with the provisos of minimising impact on employment and economic stability. This framework could facilitate stable policy and investment through greater levels of certainty and predictability and provide a credible pathway to decarbonisation.

\subsubsection{The Influence of Powerful Vested Interests}

Climate policy requires investment in new technologies and a fundamental change in the harvesting of energy sources. There are thus enormous benefits to be gained by investors in new technologies, but some of the most powerful industries dependent on mining, transporting and marketing fossil fuels for their ongoing hegemony face decline and irrelevance in the process of decarbonisation. Fossil fuel companies and their associated lobbyists have significant access to bureaucrats, politicians and regulators, which provide opportunities for 
a revolving door between industry, the public service and politicians. A good example of this emerged after investigations into the Deepwater Horizon oil spill highlighted how the cosy relationships between industry and the regulator led to 'principal capture' (Neill and Morris 2012).

Research into Appalachian coal regions shows that they are dependent on the coal industry for economic opportunity, their cultural identity as rural Americans and their sense of worth. As demand for coal in the USA has declined since 2009, the coal industry has framed environmentalism as the cause of economic decline in coal regions. Fear of job losses as a result of mine closures has resulted in significant electoral anger against climate policy and the election of politicians opposed to decarbonisation (Lewin 2017). Other research finds that communities that host coal mines tend to have high poverty, poor health outcomes (Hendryx 2011) and reduced economic development compared to non-coalmining communities. As coal miners are paid relatively high wages for low-skilled work, there is a disincentive to improve education, which increases risk of unemployment as the sector mechanises or contracts (Douglas and Walker 2017). Policies intended to promote employment from coal extraction will come at the price of lower long-term income growth. Policy-makers are advised to use the current income from fossil fuel extraction to promote economic diversification to prepare for adaptation (Douglas and Walker 2017).

Thus, decarbonising is not the techno-economic win-win solution as it is commonly framed by engineers, economists and policy-makers. In reality, decarbonisation is characterised by power structures, control of resources and political economy, all of which will result in a deeply political struggle (Healy and Barry 2017). There is increasing reference to a 'just transition' for workers who bear the burden of decarbonisation policies (Mayer 2018), but it is important to recognise that there needs to be a transition 'to' something tangible, not a theoretical shift to some unknown new opportunity. For this reason, it is essential that climate/energy policy interacts closely with economic development to channel employment away from fossil fuel extraction to specific new opportunities also located in rural settings. Proposals like Ross Garnaut's development of Australian renewable energy resources to underpin a low-cost manufacturing hub (Garnaut 2019) and the Asian Renewable Energy Hub (Asian Renewable Energy Hub 2018) proposed to be developed by a consortium including InterContinental Energy, Macquarie Capital and Vestas (cwpRenewables 2018), are evidence of the potential of this interaction of climate/energy policy and economic development.

\subsubsection{Pathways and Roadmaps to Decarbonisation Resilience}

There are many pathways to deep decarbonization, and they do not require major technological breakthroughs.

(The White House 2016: 30)

Context is crucial. A country that is reliant on coal for electricity generation and export income will pursue a different pathway to one that has few energy resources and historically has been reliant on imports of energy for economic development. Equally, a country 
that has little electricity infrastructure will consider a different roadmap to one that has an ageing, inefficient fleet of high-emission generators. Countries where politics is driven by a conceptual framework of free markets will choose different policy mixes to those more comfortable with the welfare state. Pathways and roadmaps will be determined by context and the elements of climate policy, identified in Sections 1.2.1 and 1.2.2 above, applied as appropriate.

In particular, every nation, city, region and industry needs to address public commitment to elements of climate policy that are acceptable. Public antipathy to carbon pricing led to its demise in Australia. Irrespective of its economic credentials, forcing the public to accept a carbon price when there is antipathy to such a device will lead to a roadblock to decarbonisation. Instead, if the pursuit of higher levels of RE has broad public support, then it is more effective to pursue an RET. Decarbonisation pathways require a framework of policy measures that are supported by and acceptable to the public. In the absence of a more technocratic approach to decarbonisation, a framework based on popular policy measures will: garner political support and facilitate the prompt roll-out of mechanisms to guide the process of both mitigation and adaptation; ensure that decarbonisation follows a consistent pathway, avoiding political interference which leads to competing and contradictory policy agendas and a stop-go approach to policies; develop a pathway based on a diverse combination of policy measures that together will accelerate investment and behaviour modification to mitigate against and adapt to climate change; and facilitate adaptation to changing circumstances using a multiplicity of policy tools, thereby avoiding reliance on any one single tool and allowing the introduction of new tools into the framework to address gaps or changes in requirement. This democratisation of decarbonisation policy could provide a more powerful and durable framework to achieve targets in the requisite time frames. So too, strong climate policies need to recognise and tackle the inevitable impact on some communities from decarbonisation. The disenfranchisement felt in America's industrial heartland saw the Trump Administration retreat from the global climate leadership and policies of the Obama Administration - arguably because not enough was done to provide the necessary social support through what is in essence a form of profound structural adjustment.

\section{References}

AAP (Australian Associated Press) (2017). SA to go it alone on power quest. SBS Korean. 10 February. Available at: www.sbs.com.au/language/english/sa-to-go-it-alone-onpower-quest.

AEMC (Australian Energy Market Commission) (2012). Power of Choice Review: Giving Consumers Options in the Way They Use Electricity. Sydney: Australian Energy Market Commission.

AEMO (Australian Energy Market Operator) (2019). Integrated System Plan (ISP). Melbourne: Australian Energy Market Operator. Available at: www.aemo.com.au/ Electricity/National-Electricity-Market-NEM/Planning-and-forecasting/IntegratedSystem-Plan. 
Anderson, P. and Tushman, M. L. (1990). Technological discontinuities and dominant designs: A cyclical model of technological change. Administrative Science Quarterly, 35, 604-633.

Arthur, W. B. (1989). Competing technologies, increasing returns, and lock-in by historical events. The Economic Journal, 99, 116-131.

Asian Renewable Energy Hub (2018). Renewable Energy at Oil and Gas Scale. Available at: https://asianrehub.com/.

Baer, H. A. (2016). The nexus of the coal industry and the state in Australia: Historical dimensions and contemporary challenges. Energy Policy, 99, 194-202.

Barbier, E. B. (2003). The role of natural resources in economic development. Australian Economic Papers, 42, 253-272.

Bayulgen, O. and Ladewig, J. W. (2017). Vetoing the future: Political constraints and renewable energy. Environmental Politics, 26, 49-70.

Brown, M. A. and Sovacool, B. (2011). Barriers to the diffusion of climate-friendly technologies. International Journal of Technology Transfer and Commercialization, $10,43-62$.

CAIT Climate Data Explorer (2019). Country Greenhouse Gas Emissions. Washington, DC: World Resources Institute. Available at: http://cait.wri.org.

Chan, G. (2017). Coalition says it may change Clean Energy Finance Corporation rules to fund coal plants. The Guardian. 19 February.

Christensen, C. M. (1997). The Innovator's Dilemma: How New Technologies Cause Great Firms to Fail. Boston, MA: Harvard Business School Press.

Compston, H. and Bailey, I. (2012). Climate Clever: How Governments Can Tackle Climate Change (and Still Win Elections). Florence, KY: Taylor and Francis.

Coorey, P. (2019). Coalition eyes funding for carbon capture. Australian Financial Review. 18 November.

CPUC (California Public Utilities Commission) (2019). Integrated Resource Plan and Long Term Procurement Plan (IRP-LTPP). San Francisco, CA: California Public Utilities Commission. Available at: www.cpuc.ca.gov/irp/.

cwpRenewables (2018). Asian Renewable Energy Hub. Available at: https:// cwprenewables.com/projects/asian-renewable-energy-hub/.

Douglas, S. and Walker, A. (2017). Coal mining and the resource curse in the Eastern United States. Journal of Regional Science, 57, 568-590.

Eurelectric (2015). A Reference Model for European Capacity Markets. Eurelectric position paper. Available at: www.eurelectric.org/media/1918/a_reference_model_for_ european_capacity_markets-2015-030-0145-01-e.pdf.

European Commission (2009). European Energy Programme for Recovery. Brussels: European Commission. Available at: http://ec.europa.eu/energy/eepr/projects/.

European Commission (2011). A Roadmap for Moving to a Competitive Low Carbon Economy in 2050. Brussels: European Commission. Available at: www.europarl. europa.eu/meetdocs/2009_2014/documents/com/com_com(2011)0112_/com_com (2011)0112_en.pdf [English translation].

Garnaut, R. (2019). Superpower: Australia's Low-Carbon Opportunity. Melbourne: La Trobe University Press.

German AEE (Renewable Energies Agency) (2016). Acceptance of renewable energy in Germany. Available at: www.unendlich-viel-energie.de/english/acceptance-of-renew able-energy-in-germany.

German AEE (2019). Important for the fight against climate change: Citizens want more renewable energies. Available (in German) at: www.unendlich-viel-energie.de/akzep tanzumfrage-2019. 
German BMU (Federal Ministry of the Environment, Nature Conservation and Nuclear Safety) (2009). Cost and Benefit Effects of Renewable Energy Expansion in the Renewable and Heat Sectors. Berlin: German Federal Ministry of the Environment, Nature Conservation and Nuclear Safety. Available at: www.ctc-n.org/resources/ cost-and-benefit-effects-renewable-energy-expansion-german-power-and-heatmarket.

Goodman, J. (2008). The minerals boom and Australia's resource curse. Journal of Australian Political Economy, 61, 201-219.

Han, J. and Yun, S.-J. (2015). An analysis of the electricity consumption reduction potential of electric motors in the South Korean manufacturing sector. Energy Efficiency, 8, 1035-1047.

Harrington, W., Morgenstern, R. D. and Sterner, T., eds. (2004). Choosing Environmental Policy: Comparing Instruments and Outcomes in the United States and Europe. Washington, DC: Resources for the Future.

Healy, N. and Barry, J. (2017). Politicizing energy justice and energy system transitions: Fossil fuel divestment and a 'just transition'. Energy Policy, 108, 451-459.

Hendryx, M. (2011). Poverty and mortality disparities in Central Appalachia: Mountaintop mining and environmental justice. Journal of Health Disparities Research and Practice, 4, 44-53.

Hirst, E. and Brown, M. (1990). Closing the efficiency gap: Barriers to the efficient use of energy. Resources, Conservation and Recycling, 3, 267-281.

IEA (International Energy Agency) (2014). Emissions Reduction through Upgrade of Coal-Fired Power Plants: Learning from Chinese Experience. Paris: OECD.

IEA (2019a). SDG7: Data and Projections: Access to Affordable, Reliable, Sustainable and Modern Energy for All. Paris: International Energy Agency. Available at: www .iea.org/reports/sdg7-data-and-projections/access-to-electricity\#abstract.

IEA (2019b). World energy balances. IEA World Energy Statistics and Balances [database]. Available at: https://doi.org/10.1787/data-00512-en.

IEA (2019c). $\mathrm{CO}_{2}$ emissions by product and flow. IEA $\mathrm{CO}_{2}$ Emissions from Fuel Combustion Statistics [database]. Available at: https://doi.org/10.1787/data-00430-en.

IEA (2019d). World Energy Outlook 2019. Paris: International Energy Agency.

Jakob, M. and Steckel, J. C. (2014). How climate change mitigation could harm development in poor countries. WIREs Climate Change, 5, 161-168.

Jasper, J. M. (2014). Nuclear Politics: Energy and the State in the United States, Sweden, and France. Princeton: Princeton University Press.

Joas, F., Pahle, M., Flachsland, C. and Joas, A. (2016). Which goals are driving the Energiewende? Making sense of the German Energy Transformation. Energy Policy, 95, 42-51.

King, S. (2015). Smart meters, dumb policy: The Victorian experience. The Conversation. 17 September. Available at: https://theconversation.com/smart-meters-dumb-policythe-victorian-experience-47685.

Künneke, R. W. (2008). Institutional reform and technological practice: The case of electricity. Industrial and Corporate Change, 17, 233-265.

Lazard (2019). Levelized cost of energy analysis: Version 13. Lazard. 7 November. Available at: www.lazard.com/perspective/lcoe2019.

Lenhart, S., Nelson-Marsh, N., Wilson, E. J. and Solan, D. (2016). Electricity governance and the Western energy imbalance market in the United States: The necessity of interorganizational collaboration. Energy Research \& Social Science, 19, 94-107.

Lewin, P. G. (2017). 'Coal is not just a job, it's a way of life': The cultural politics of coal production in Central Appalachia. Social Problems, 66, 51-68. 
Mahmoudi, N., Heydarian-Forushani, E., Shafie-Khah, M., Saha, T. K., Golshan, M. E. H. and Siano, P. (2017). A bottom-up approach for demand response aggregators' participation in electricity markets. Electric Power Systems Research, 143, 121-129.

Mayer, A. (2018). A just transition for coal miners? Community identity and support from local policy actors. Environmental Innovation and Societal Transitions, 28, 1-13.

Meadowcroft, J. (2011). Engaging with the politics of sustainability transitions. Environmental Innovation and Societal Transitions, 1, 70-75.

Merzian, R., Quicke, A., Bennett, E., Campbell, R. and Swann, T. (2019). Climate of the Nation. Research report. Canberra: The Australia Institute. Available at: https:// australiainstitute.org.au/report/climate-of-the-nation-2019/.

Metherell, L. and Hawley, S. (2013). Tony Abbott says ETS a 'market in an invisible substance'; Labor denies scrapping carbon price will leave $\$ 6 \mathrm{bn}$ budget hole. $A B C$ News. 15 July. Available at: www.abc.net.au/news/2013-07-15/abbott-dismisses-etsas-market-in-an-invisible-substance/4820564.

Moe, E. (2010). Energy, industry and politics: Energy, vested interests, and long-term economic growth and development. Energy, 35, 1730-1740.

Molyneaux, L., Brown, C., Wagner, L. and Foster, J. (2016). Measuring resilience in energy systems: Insights from a range of disciplines. Renewable and Sustainable Energy Reviews, 59, 1068-1079.

Neill, K. A. and Morris, J. C. (2012). A tangled web of principals and agents: Examining the Deepwater Horizon oil spill through a principal-agent lens. Politics and Policy, 37, 1047-1072.

Nelson, R. R. (1995). Recent evolutionary theorizing about economic change. Journal of Economic Literature, 33, 48-90.

Ordanini, A., Miceli, L., Pizzetti, M. and Parasuraman, A. (2022). Crowd-funding: Transforming customers into investors through innovative service platforms. Journal of Service Management, 22, 443-470.

Osofsky, H. and Wiseman, H. (2014). Hybrid energy governance. University of Illinois Law Review, 2014, 1-66.

Parliament of Australia (2011). Commonwealth Parliamentary Debates, House of Representatives. No. 14, 2011. Wednesday, 21 September. Canberra: Hansard.

Parliament of Australia (2016). Corporations Amendment (Crowd-Sourced Funding) Bill: Explanatory Memorandum. Canberra: Parliament of Australia. Available at: www .aph.gov.au/Parliamentary_Business/Bills_Legislation/Bills_Search_Results/Result? $\mathrm{bId}=\mathrm{r} 5766$.

Pew Research Center (2016). The Politics of Climate [survey]. Available at: www .pewresearch.org/science/2016/10/04/the-politics-of-climate/.

Pregger, T., Nitsch, J. and Naegler, T. (2013). Long-term scenarios and strategies for the deployment of renewable energies in Germany. Energy Policy, 59, 350-360.

Reserve Bank of Australia (2013). Statement on the conduct of monetary policy. Reserve Bank of Australia. 24 October. Available at: www.rba.gov.au/monetary-policy/frame work/stmt-conduct-mp-6-24102013.html.

Rhys, J. (2010). Reforming UK electricity markets. Oxford Energy Forum, 81, 20-23. Available at: www.oxfordenergy.org/wpcms/wp-content/uploads/2011/02/OEF-81 .pdf.

Rhys, J. (2014). Back to the CEGB? Greater central control of UK energy may be inevitable. The Conversation. 9 May. Available at: https://theconversation.com/back-tothe-cegb-greater-central-control-of-uk-energy-may-be-inevitable-26474.

Sachs, J. D. and Warner, A. M. (1997). Fundamental sources of long-run growth. The American Economic Review, 87, 184-188. 
Scobie, C. (2016). Supreme Court stays EPA's clean power plan. American Bar Association. 17 February. Available at: www.americanbar.org/groups/litigation/com mittees/environmental-energy/practice/2016/021716-energy-supreme-court-staysepas-clean-power-plan/.

Simshauser, P. (2019). Missing money, missing policy and resource adequacy in Australia's National Electricity Market. Utilities Policy, 60.

St John, A. (2016). What's happening with ARENA? Flagpost. 19 September. Available at: www.aph.gov.au/About_Parliament/Parliamentary_Departments/Parliamentary_ Library/FlagPost/2016/September/ARENA-changes.

Sue, K., Macgill, I. and Hussey, K. (2014). Distributed energy storage in Australia: Quantifying potential benefits, exposing institutional challenges. Energy Research \& Social Science, 3, 16-29.

Tellus (2000). Best Practices Guide: Integrated Resource Planning for Electricity. Washington, DC: United States Agency for International Development.

Teske, S. (2019). Achieving the Paris Climate Agreement Goals: Global and Regional $100 \%$ Renewable Energy Scenarios with Non-Energy GHG Pathways for $+1.5^{\circ} \mathrm{C}$ and $+2{ }^{\circ} C$. Switzerland: Springer Nature.

The White House (2016). United States Mid-Century Strategy for Deep Decarbonization. Washington, DC: The White House. Available at: https://unfccc.int/files/focus/longterm_strategies/application/pdf/mid_century_strategy_report-final_red.pdf.

Thomas, S. (2016). A perspective on the rise and fall of the energy regulator in Britain. Utilities Policy, 39, 41-49.

Tong, D., Zhang, Q., Zheng, Y., Caldeira, K., Shearer, C., Hong, C., Qin, Y. and Davis, S. J. (2019). Committed emissions from existing energy infrastructure jeopardize $1.5^{\circ} \mathrm{C}$ climate target. Nature, 572, 373-377.

UK CCC (Committee on Climate Change) (2008). Building a Low-Carbon Economy: The UK's Contribution to Tackling Climate Change. London: UK Committee on Climate Change.

UK CCC (2009). Meeting Carbon Budgets: The Need for a Step Change. London: UK Committee on Climate Change.

UK GIG (Green Investment Group) (2019). Progress Report: Accelerating the Transition to a Greener Global Economy. Sydney: UK Green Investment Group. Available at: https://greeninvestmentgroup.com/media/230066/gig-progress-report-2019_final-a4 .pdf.

UK OFGEM (Office of Gas and Electricity Markets) (2016). Integrated Transmission Planning and Regulation. UK Office of Gas and Electricity Markets. Available at: www.ofgem.gov.uk/electricity/transmission-networks/integrated-transmission-plan ning-and-regulation.

Unruh, G. C. (2000). Understanding carbon lock-in. Energy Policy, 28, 817-830.

US DOE (Department of Energy) (1978). Power Plant and Industrial Fuel Use Act. energy. gov. Available at: https://energy.gov/oe/services/electricity-policy-coordination-andimplementation/other-regulatory-efforts/power-plant.

US EIA (Energy Information Administration) (2019a). Existing nameplate and net summer capacity by energy source, producer type and state (EIA-860) [data resource]. US Energy Information Administration. Available at: www.eia.gov/electricity/data/state/.

US EIA (2019b). Table 9.1 emissions from energy consumption at power plants [data resource]. US Energy Information Administration. Available at: www.eia.gov/electri city/data.php\#elecenv.

US EPA (Environmental Protection Agency) (2015). Overview of the Clean Power Plan: Cutting carbon pollution from power plants. United States Environmental Protection 
Agency. Available at: https://archive.epa.gov/epa/cleanpowerplan/fact-sheet-over view-clean-power-plan.html.

US EPA (2019). Affordable Clean Energy Rule. United States Environmental Protection Agency. Available at: www.epa.gov/stationary-sources-air-pollution/affordableclean-energy-rule.

Wang, X. and Lin, B. (2017). Impacts of residential electricity subsidy reform in China. Energy Efficiency, 10, 499-511.

Wang, Y. and Brown, M. A. (2014). Policy drivers for improving electricity end-use efficiency in the USA: An economic-engineering analysis. Energy Efficiency, 7, 517-546.

Warren, B., Christoff, P. and Green, D. (2016). Australia's sustainable energy transition: The disjointed politics of decarbonisation. Environmental Innovation and Societal Transitions, 21, 1-12.

Williamson, O. E. (1998). Transaction cost economics: How it works; where it is headed. De Economist, 146, 23-58.

Wirth, H. (2017). Recent Facts about Photovoltaics in Germany. Freiburg: Fraunhofer Institute. 
